\title{
One Size Does Not Fit All: Framing Smart City Policy Narratives within Regional Socio-Economic Contexts in Brussels and Wallonia
}

\author{
Giovanni Esposito *a \\ Jessica Clement $^{\text {a }}$ \\ Luca Mora $^{b}$ \\ Nathalie Crutzen ${ }^{\text {a }}$ \\ ${ }^{a}$ HEC Liège Management School, University of Liège \\ $\mathrm{b}$ The Business School, Edinburgh Napier University
}

* Corresponding author at: HEC Liège Management School, University of Liège, Rue SaintGilles, 35B - 4000 Liège (Belgium). Phone: +32 423273 59; E-mail address: gesposito@uliege.be

\begin{abstract}
Smart city initiatives are increasingly dominating urban policy scripts worldwide, and their diffusion is centered upon different regional strategies. Adopting the Narrative Policy Framework as methodological basis, this article examines the smart city strategies developed by the Wallonia and Brussels-capital regions during the 2014-2019 period. Moving away from corporate-led deterministic models of smart city development, it shows that there is no onesize-fit-all approach to smart urbanism. Regional governments attribute different meanings to urban innovation and formulate place-based strategies of smart city development in relation to their socio-economic contexts, seeking to advance technological solutions to what they perceive as the most pressing problems of their territories and populaces.
\end{abstract}

Keywords: smart city policies, regional governments, Narrative Policy Framework, socio-economic context 


\section{Introduction}

Smart city initiatives are complex transformational processes consisting of profound modifications of 'soft' and 'hard' components of existing urban regimes (Angelidou, 2014; Wahlström et al., 2020). These initiatives can be understood as urban strategies to advance technological solutions to the pressing sustainability issues facing policymakers (Viitanen \& Kingston, 2014; Karppi \& Vakkuri, 2020). Inspired by different modes of leadership, smart city initiatives aim to improve the capability of city governments to exploit digital innovation for boosting urban sustainability (Mora \& Deakin, 2019; Sancino \& Hudson, 2020). Their implementation builds on government-led innovation ecosystems in which large collaborative networks composed of heterogeneous actors organize in a quadruple-helix organizational setting (Mora et al. 2019b; Nesti \& Graziano, 2020; Timeus et al., 2020; Drapalova \& Wegrich, 2020).

Because of this complexity, the smart city concept often appears nebulous and ambiguous (Shelton et al., 2015: 13) with practitioners attributing different meanings to it (Angelidou, 2014; Anthopoulos, 2017; Kitchin, 2015; Korachi \& Bounabat, 2020; Lazaroiu \& Roscia, 2012). These meanings range from a holistic interpretation - with a broad focus encompassing sustainability and civic participation issues - and to a more reductionist interpretation - with a narrow focus on technological deployment (Mora et al., 2019a). Nevertheless, despite its ambiguity, the smart city concept is increasingly dominating urban policy scripts through narratives that shape the strategic development of urban technologies (Lorquet et Pawels, 2020; Söderström, 2014; Visser, 2019). Within this context, this article explores how narratives, while reducing the ambiguity of the smart city concept, contribute to frame the strategic development smart city initiatives. Narratives are indeed pivotal to the strategic management of complex urban innovation projects (Esposito et al., 2020). They create coherence and order in the cognitive universe of all concerned actors (Weick, 1995) through sense-making, the process by which actors give meaning to their collective experiences (Weick et al., 2005). As "new imagination of alternatives" (Sandercock, 2003: 18), smart city narratives provide actors with a common understanding of future city challenges and possible solutions (Söderström, 2014). From this viewpoint, smart city development can be seen as "emplotment, characterizations, descriptions of settings, and rhythm and imagery of language" (Throgmorton, 2003: 126).

By shaping concepts and imaginaries about how ICTs will improve urban sustainability, smart city narratives convey ideas and practices which are transmitted and reproduced within different local city contexts around the globe (Joss et al., 2019). Nevertheless, notwithstanding the worldwide permeation of these narratives, research has acknowledged the diversity of smart city narratives within local contexts (Desdemoustier et al., 2019a; 2019b) suggesting that the choice of a narrative over another is very dependent on local contextual parameters such as, for example, the perception of new technologies, attitude towards privacy and cultural heuristics (Csukás \& Szabó, 2021; Ruhlandt, 2018). A key role in the development and formulation of these local narratives may be played by regional governments whose strategies for smart city implementation within their territories have a powerful influence on local actors, for example, by offering financial support to municipalities in return for compliance with 
proposed regional strategies (Adapa et al., 2018; Yang \& Li, 2013; Ye, 2014). Indeed, as national and regional governments sense the importance of sustainable development and industrial transformation ( $\mathrm{Li} \&$ Wang, 2012), smart city narratives can be increasingly found in various supra-municipal urban development plans aimed at encouraging municipal policymakers to advance technological solutions for boosting urban sustainability (de Jong et al., 2016; Liu et al., 2014). In a similar vein, (Lu \& de Jong, 2019: 157) argue that "for the implementation of national protocols at the local level in planning, governments often use regional strategies and visions as an intermediate step". To put it bluntly, regional governments' policies are important because they convey narratives that connect local smart city initiatives to the socio-economic needs of the regional contexts (Tang et al., 2019). Regional policy texts embedding smart city strategies are thus documents of major concern for analysis. Nevertheless, despite their importance, regional smart city policy narratives have remained an under-explored area of investigation. So far, scholars have explored smart city narratives emerging from scientific publications (Mora et al., 2019a), corporate texts (Söderström et al., 2014), and the opinions of municipal policymakers operating within different local contexts (Desdemoustier et al., 2019b) but little attention has been paid to regional policy texts. Therefore, this paper contributes to fill such a knowledge gap with a comparative case study analysis guided by the following research question: how do regional governments operating within different socio-economic contexts develop different smart city policy narratives?

To answer this question, our analysis follows the Narrative Policy Framework (NPF) approach to explain how regional governments formulate policy narrative plots to make sense of their environment (settings), to attribute roles to key actors (characters) and to identify policy solutions for implementation (moral) (Jones et al., 2014; Weible \& Sabatier, 2017). While the NPF has been widely applied to a variety of public policy domains - climate change (Jones \& Song, 2014), education (Ertas, 2015), disaster management (Crow et al., 2017) finance campaign regulation (Gray \& Jones, 2016), public administration reforms (Weiss, 2020), to mention but a few - no study so far has empirically applied this framework to the analysis of smart city policies.

As for the empirics, we choose a comparative case-study research approach. This approach is well suited to address how questions (Yin, 2014; Flyvbjerg, 2001) - such as the one at the basis of this article - involving an in-depth and detailed examination of the phenomenon under observation - here the different smart city policy narratives developed by regional governments operating within different socio-economic contexts. We choose Belgium as empirical site because this is one the of the most high-performing European Union's countries in the area of digital policy (European Commission, 2018) and because the smart city transformational process is actively happening in this country (e.g. Simonofski et al., 2019; Desdemoustier et al. 2019a, 2019b; Van den Bergh \& Viaene, 2016; Walravens, 2015). In Belgium, we particularly choose to study the policy texts for smart city development adopted by the Walloon and Brussels ${ }^{1}$ regional governments during the 2014-2019 period because they adopt two

\footnotetext{
${ }^{1}$ In this paper, the term Brussels government refers to the Brussels-Capital Region. This region comprises 19 Belgian municipalities, which includes the City of Brussels.
} 
different smart city strategies within two different socio-economic regional contexts. Therefore, Wallonia and Brussels' regional strategies for smart city development can be regarded as two typical cases of smart city policy narratives developed by regional governments operating within different socio-economic contexts, thus exemplifying "what is considered to be a typical set of values, given some general understanding of a phenomenon' (Gerring, 2006: 91).

Innovatively building on NPF, we argue that regional governments operating within different socio-economic contexts develop different smart city policy narratives that reflect different place-based regional interpretations of the smart city concept. Because of these different interpretations, such governments understand and use smart city projects as policy instruments to solve what they consider the most pressing socio-economic problems of their territories and populaces. Based on these findings, we argue that there is no one-size-fit all approach to smart urban policies and we call for an active role of regional governments in the formulation of place-based smart city strategies that are aligned with the socio-economic needs of their territories and reflect the ambitions of their populaces.

The paper is organized as follows. Section 2 reviews the literature on smart cities and regional policy narratives. Section 3 describes case studies, data and methods. Section 4 reports on the results of the analysis. Sections 5 and 6 provide the discussion and conclusion, respectively.

\section{Smart cities and regional policy narratives}

\subsection{Smart city: an ambiguous concept susceptible to multiple place-based interpretations}

The concept of "smart city" is increasingly dominating urban public policy scripts around the world (Lorquet \& Pauwels, 2020; Visser, 2019). It is introduced as a new paradigm to think of and organize the sustainable development of urban areas (Acuto \& Parnell, 2016; Viitanen \& Kingston, 2014) and, in particular, to exploit ICTs for developing livable, competitive and sustainable cities (Greco \& Bencardino, 2014). To put it bluntly, a smart city is a city using ICTs to achieve: (1) resource efficient, safe, inclusive and accessible urban environments; (2) economic growth based on the principles of environmental sustainability and inclusive prosperity; and (3) equal access for all to public goods and high-quality services (United Nations, 2015). However, achieving such objectives through smart city innovations is a complex transformational process that involves multiple and interconnected changes at the level of "hard" (e.g. buildings, energy grids, water networks, mobility) and "soft" (e.g. human and social capital, urban culture) components of urban systems (Angelidou, 2014). These changes can be grouped in three main categories (Meijer \& Bolívar 2016): technology, human resources, and governance. While the technological dimension brings the focus on the introduction of loads of ICT solutions in urban systems as the key factor for smart city development (Washburn \& Sindhu, 2010), the other two categories focus on non-technological components. Cities require human capital to enable smart-city-related transition processes (Hollands, 2008; Shapiro, 2006), but also collaborative environments for technology to be correctly integrated and deployed in the urban environment (Torfing, 2016). The smart city concept is therefore multidimensional and consists of multiple features like enhancing the 
quality of life, adopting ICTs in urban systems, implementing new governance, focusing on human capital, favouring public value creation, supporting innovation and reaching a more sustainable territory (Appio et al., 2019; Batty et al., 2012; Giffinger et al., 2007; Ibrahim et al., 2018; Ramaswami et al., 2016).

Because of such conceptual multidimensionality, "the smart city is a somewhat nebulous idea" (Shelton et al., 2015: 13). It is ambiguous and practitioners often see it as fuzzy, thus attributing different meanings to it (Angelidou, 2014; Anthopoulos, 2017; Kitchin, 2015; Korachi \& Bounabat, 2020; Lazaroiu \& Roscia, 2012). Policymakers have therefore cultivated different interpretations of the smart city concept, ranging from a holistic view - with a broad focus encompassing sustainability and civic participation issues - and to a more reductionist understanding - with a narrow focus on technological deployment (Mora et al., 2019a). Research by Desdemoustier et al. (2019b), for example, shows that a holistic view of smart cities prevails among policymakers operating in medium- and large-size Belgian municipalities. Conversely, policymakers operating in rural areas and small size municipalities either do not have any understanding of smart cities or display a narrow technology-focused interpretation. Narrowing down the focus on the holistic view of smart cities, Csukas \& Szabo (2021) undertake a comparative study of smart city strategies in Amsterdam, Barcelona, London, Helsinki, New York, Vienna, Berlin, Budapest and Moscow. Four different development strategies emerge from their analysis: (1) focusing on environmentally related objectives; (2) focusing on developing and rolling out platforms and ICT applications to provide quality of life improvements directly for citizens; (3) focusing on social inclusion activities such as involving innovations that deal with elderly care, better working conditions for disabled people, or helping immigrants to settle; (4) focusing on activities that facilitate citizen engagement in urban governance. Consistently with Ruhlandt (2018), this work argues that the choice of a strategy over another is very dependent on local contextual parameters such as the perception of new technologies, attitude towards privacy and cultural heuristics. In line with this evidence, Tang et al. (2019) argue that city governments have different place-based interpretations of smart city development because they operate in different urban local environments where residents experience different practical problems. Bringing the focus on the broader social, technological and, economic environment in which policymakers operate, their work explains that decision making is not only affected by the needs expressed by local dwellers but it is also affected by the technological affordances of available ICT solutions and exiting urban infrastructures, as well as by the budgetary constraints that limit public and private investments. Adopting an inductive method of analysis, they examine the smart city plans of 60 municipalities and single out four different development models, which are largely associated with specific attributes of the urban environment: (1) the broad-spectrum (holistic) model of major metropolitan areas, which are economically prosperous and/or embed provincial or national capitals; (2) the business ecosystem model of cities transitioning from former transportation hubs and manufacturing centers to high-tech entrepreneurial economies; (3) the smart transportation model, which surfaces from rich and congested population centers with a history of business activity in high technology and finance; and, (4) the essential services model, which relates to urban environments where smartphone-based information systems are widely diffused in the day-to-day activities of the local population. Echoing (Nam \& Pardo, 
2011: 190), this work argues that there is no one-size-fits-all approach for smart city development and that "city governments' imperative is thus to establish a set of clearly articulated strategies that are well-situated in the environmental context". These are indeed place-based strategies that are not made in a void but based on existing economic and regional contexts (Lu \& de Jong 2019). The objective of such place-based choices is to contribute to the efficient economic and social functioning of a place consistently with the broader goals that urban planners have established for the place (Ashworth \& Voogd, 1990). Therefore, placebased solutions for cities can reflect both their status quo and the future ambitions set by city planners (de Jong et al., 2018; Han et al., 2018; Merrilees et al., 2012).

While municipal policymakers are pivotal to the implementation of place-based smart city strategies, very often the design of these initiatives is steered by national and regional governments (de Jong et al., 2016; Esposito et al., 2021; Liu et al., 2014; Tang et al., 2019; Yang \& Li, 2013; Ye, 2014). This is confirmed by Lu and de Jong (2019: 157) arguing that "for the implementation of national protocols at the local level in planning, governments often use regional strategies and visions as an intermediate step". Regional policy texts for urban development have indeed a significant impact on cities' growth, development and image (Yang $\& \mathrm{Li}, 2013$; Ye, 2014) and exert powerful harmonizing influence on smart city initiatives developed at the municipal level (Tang et al., 2019)

\subsection{Unpacking regional smart city strategies through narrative policy analysis}

Since the 1990s, as the social sciences underwent their discursive turn, there has been a wide recognition within urban planning theory of the role of storytelling (Van Hulst, 2012). "Stories are central to planning practice" - say Sandercock (2003: 12) - "the way we narrate the city becomes constitutive of urban reality, affecting the choices we make, the ways we then might act". However, as argued by Potter (2020: 1537), "stories are not mean here in a superficial sense, as an aesthetic narrative that is belatedly brought to a space to explain or adorn that environment. They refer instead to expressions of ontological and epistemological imaginaries, manifested or enacted in the making [...] of a place. In this sense, practices of formalized urban place-making like urban planning are modes of expressions - they give voice to narratives of human/environment relations". Indeed, "although we might consider this discursive activity with some skepticism, it often makes a difference. It is performative, because it shapes the imaginaries and practices of a myriad of actors concretely building the city" - says Söderström (2014: 307). Therefore, the narrative analysis of key planning texts is a powerful instrument to unpack place-based strategies of urban development through which policy makers represent their socio-economic environment, the problems to be solved in this environment and possible

solutions. Indeed, the way governments understand and label urban problems is central to determine policy intervention (Lascoumes \& Le Gales, 2007).

Introduced as a new paradigm to think of and organize the sustainable development of urban areas through the use of ICTs (Acuto \& Parnell, 2016; Greco \& Bencardino 2014; Viitanen \& Kingston, 2014), over the last decade smart city narratives have become a major leitmotif in the discourse on urban development (Crivello, 2015) and have spread in a variety of local contexts (Franco \& Ortiz, 2020). Cowley et al.'s (2018) analysis of smart city initiatives across six British cities show that local smart city practices have a strong discursive component 
(pamphlets, websites, etc.) while spatio-physical articulations may remain ephemeral, thus concluding that these initiatives were largely determined by a national discourse on "future cities" instigated by the UK government. Joss et al. (2019) analyze diverse online policy documents produced by a wide range of smart city stakeholders (municipal authorities, national agencies, international organizations, think tanks, consultants, etc.), thus presenting the smart city paradigm as a strong international narrative involving a network of 27 (mostly capital or world) cities in Asia, Europe, and North America. The narrative embedded in these texts consists of multiple dimensions that go beyond the infrastructure-technology understanding of smart city in order to encompass issues of participatory governance and, to a lesser extent, of environmental sustainability. Following-up on this line of inquiry, Desdemoustier et al.'s (2019a) work on Belgian smart cities shows that this international narrative on smart cities has been approached differently by local policymakers depending on the future societal problems - e.g. traffic congestion, environmental pollution, increased participation in the city management, etc. - they want to solve in their local context through the use of ICTs. Framed as such, the "smart city is more of a strategy than a reality, a strategic vision for the future" (Angelidou et al., 2018: 7). More precisely, it is a strategic narrative - intended here as a written and a spoken story of an imagined future captured in a 'before,' 'now,' and 'to be' sequence (Barry \& Elmes, 1997) - shaped by aspects such as the local context and the socio-economic challenges of the target city, the challenges and desires that motivate city policymakers at different levels of government (Sadowski \& Bendor, 2019).

As mentioned above, urban development strategies adopted by regional governments exert powerful influence on the smart city initiatives developed at the municipal level (de Jong et al., 2016; Liu, Zhou, Wennersten, \& Frostell, 2014; Tang et al., 2019; Yang \& Li, 2013; Ye, 2014). However, notwithstanding the importance of regional policy texts, smart city scholars have mainly explored narratives emerging from scientific publications (Mora et al., 2019), corporate storytelling (Söderström et al., 2014), and municipal policymakers (Desdemoustier et al., 2019a, 2019b), while regional smart city policy strategies still remain an under-explored area of investigation. In addressing the analysis of regional smart city narratives, we build on the Narrative Policy Framework (NPF), a widely spread methodological approach to explain how policymakers make sense of complex policy issues and develop stories which inform decisionmaking (Jones, 2014; Jones et al., 2014; Weible \& Sabatier, 2017). NPF defines policy narratives as discursive constructs composed of four main elements: a setting, a group of characters (victims, villains and heroes), a plot, and the moral of the story (Jones et al. 2014). The setting consists of policy-related, taken-for-granted facts characterized by very low levels of disagreement (e.g. figures provided by experts or national statistics bureaus). Characters are the relevant actors in a policy narrative, consisting of those that are harmed (victims), those that perpetuate the harm (villains), and those that will correct the situation (heroes). Similar to Greimas' (1983) notion of "actants", NPF characters may be either persons or abstractions (e.g., "the economy", "the environment", "the city" or "the territory"). The plot connects the setting to the characters and the characters to one another, spelling out the causal arrangements of the policy problem. Plots describe how the villain harms its victims, but they are also instrumental in explaining "how blame is assigned to the villain, what actions are needed from the hero and what moral is to be gleaned from the story. The moral of a policy narrative typically refers to 
the policy solutions" (Gray \& Jones, 2016: 197). Based on this rationale, policy narrative plots make it possible to understand the causal mechanism through which a government makes sense of its environment (setting), attributes roles to key actors (characters), and identifies policy solutions for implementation (moral) (Jones et al. 2014).

\section{Research design, data collection and analysis}

Using the NPF as a methodological basis, we analyze the narrative structure of the policy texts adopted by the Walloon and Brussels governments to guide the smart city development in the Wallonia and Brussels regions. Since 2014, smart city strategies are indeed initiated in both regions - i.e. Smart Brussels strategy in Brussels and Digital Wallonia strategy in Wallonia. Following Gioia et al. (2013), the research was organized on the basis of the following three steps. The first step is the research design and involves articulating a well-defined phenomenon of interest through a research question 'how' terms. The second step is the data collection and involves the use of multiple data sources - documents, interviews and, if needed be, statistics - to gather empirical insights into the phenomenon of interest. The third step is the data analysis and involves a systematic approach to the interpretation of data sources that occurs through multiple levels coding.

\subsection{Research design}

The research question at the basis of this paper is: how do regional governments operating within different socio-economic contexts develop different smart city policy narratives? To answer this question we choose Belgium as empirical site as it is one the of the most highperforming European Union's countries in this policy area (European Commission, 2018). We particularly choose to study the smart city strategies of the Wallonia and Brussels Regions for the following two reasons. First, we select Wallonia and Brussels for comparative purposes as they adopt two different models of smart city policy. The latter is closer to the holistic model, while the former proposes a narrower approach. Secondly, as we further explain below, Wallonia and Brussels have two different historical pathways that have led these regions to be very different in terms of socio-economic characteristics.

Wallonia - Since the age of the Roman Empire, Wallonia was a well-known industrial district for the production of iron and coal. In $12^{\text {th }}$ and $13^{\text {th }}$ centuries, the industrial expertise developed to such an extent that the local method of refining iron came to be known around Europe as the Walloon Method. In $14^{\text {th }}$ century, coal mines around Charleroi and the Borinage emerged and prospered for centuries until $19^{\text {th }}$ century when Wallonia was one of the most important industrial powers of the world (Destatte, 1997). Towards the mid-20 ${ }^{\text {th }}$, the end of an era began, with the coal running out and its extraction costs dramatically increasing. The crisis hit other sectors in the heavy industry - such as steel, metallurgy, glassmaking - resulting into massive industrial restructuring plans and, consequently, high unemployment rates. At beginning of the $21^{\text {st }}$ century, relaunching economic growth in the region features high on the political agenda, and the government has particularly committed to the development of high-tech industries in the ICT sector. Within this framework, in 2005 the Walloon government launched a long-term recovery plan with the popular name of the Marshall Plan. As a part of this plan, since 2015 the Walloon government has adopted Digital Wallonia, the regional strategy framing the smart 
city development in Wallonia between 2015 and 2018. It consists of 23 actions in the following 4 areas of activity: (a) empowering digital enterprises in order to increase their size in the Walloon economy; (b) reforming the public administration in order to create innovation ecosystems supporting the development and growth of digital enterprises; (c) strengthening the connectivity and smartness of the Walloon territory through better ICT infrastructures; (d) training the Walloon human capital in order to increase its digital literacy. In 2018, the impact of the regional strategy was apparent with 288 smart city projects initiated across the Walloon cities - 72\% developed by the public administration - (Vanmarsenille \& Desdemoustier 2018).

Brussels - The Brussels region has instead followed a different historical path. Grown from a small rural settlement of the Stone Age on the Senne river, the Brussels region was firstly home to Roman occupation and, when the Western Roman Empire eclipsed, to the Franks. For many centuries since the $11^{\text {th }}$ century, the region developed as an important international commercial hub for light-industry products (namely textile and clothing manufacturing) on the fluvial trade route between Bruges, Ghent and Cologne. Following the 1830 Belgian revolution, the $19^{\text {th }}$ century was a turning moment in the history of the region: Brussels rose to capital status and became the governmental seat of the newly-born nation. Because of its proximity to the newly born political institutions, the region soon became a financial hub. Following the building of the Brussels-Charleroi Canal, the region strengthened its position of commercial and manufacturing hub, growing prosperously until the $20^{\text {th }}$ century when it became the scene for various international conventions, such as the three International Expositions held in 1910, 1935 and 1958. Since the end of the Second World War, it has been a major centre for international politics and home to numerous international organizations. It has strengthened its position as financial centre of Western Europe with the creation of the largest stock exchange in continental Europe, so called Euronext Brussels. Serving also as the centre of the EU's political administration, nowadays Brussels is one of the most prosperous economies among the European regions (Eurostat, 2019), hosting world headquarters of multinationals and international organizations. Within such economically-prosperous and globalized context, in 2014 Brussels launched 'Smart Brussels', an ambitious regional strategy framing the smart city development on the basis of a holistic approach that consists of four activity areas: (a) sustainability, replacing paperwork with electronic procedures in public administrations to reduce the use of paper and car transfers from citizens' residences to municipal administrations in order to decrease the ecological footprint of public sector operations; (b) e-government, constructing new high-speed telecom networks and providing more urban areas with free WiFi connection; (c) open government, promoting open-data initiatives in order to improve citizens' access to government's work; and (d) security, creating one single regional platform of video images collected by urban cameras to improve street surveillance. In 2019, the impact of the regional strategy is apparent with hundreds of initiatives initiated in the following areas: mobility, economy, society, quality of life, government and environment ${ }^{2}$. Examples of these initiatives are a platform for citizen participation in urban policy-making ${ }^{3}$, on-line access to

\footnotetext{
${ }^{2}$ https://smartcity.brussels/s-informer\#

${ }^{3}$ https://participate.smartcity.brussels/fr-BE/
} 
public administration services (e-counters) ${ }^{4}$, new urban Wi-Fi connections and videosurveillance projects ${ }^{5}$, to mention but a few.

\subsection{Data collection}

Data collection involved firstly a qualitative stage and, subsequently, a quantitative stage (Johnson \& Onwuegbuzie 2016).

Initially, the officers in charge of smart city policies in Brussels and Wallonia were contacted to know what strategic guidelines were used to frame the design and implementation of smart city projects at the municipal level. The documents that they provided were used for the narrative analysis. Brussels adopted a policy document entitled "Smart Brussels 2014-2019", which exposes the region's philosophy on the smart city matter and provides stakeholders with a coherent understanding of most relevant smart-city challenges affecting the Brussels area. In Wallonia, the regional guidelines for smart city development are embedded in the document entitled "Digital Wallonia - Stratégie numérique de la Wallonie", which covers the 2015-2018 period. This document sets the framework for the digital transformation of the region and is structured around five strategic themes: digital sector, digital business, skills and education, public services and digital territory. Using the NPF as a basis, we undertook an in-depth analytical reading of the two governmental documents which we subsequently triangulated with complementary information sourced from two semi-structured interviews with the two key regional officials in charge of smart city strategies in Brussels and Wallonia. To strengthen the data triangulation process, additional data was also sourced from the websites 'smartcity.brussels.be' and 'digitalwallonia.be', which were used as secondary data sources because they regularly disseminate information about the implementation of regional smart city strategies.

For the purpose of complementarity and clarification of the results from the qualitative analysis, we subsequently collected quantitative information through official databases (Johnson \& Onwuegbuzie, 2016). We thus looked for socio-economic indicators offering a visual representation of qualitative information embedded in the textual material and interviews. Such indicators covered the following areas: economy, digital infrastructure, human capital and public administration (Table 1).

\section{TABLE 1 ABOUT HERE}

\subsection{Data analysis}

The two guideline texts were analyzed following tenets of interpretive research in order to discern between first order (close to the language of interviewed actors) and higher-ordered categories (Gibbs, 2007; Gioia et al., 2013) (Figure 1).

\section{FIGURE 1 ABOUT HERE}

\footnotetext{
${ }^{4}$ https://smartcity.brussels/news-757-nos-services-publics-accessibles-de-chez-vous

5 https://smartcity.brussels/news-145-le-podium-de-la-smart-city-wifi-open-data-et-durabilite
} 
Phrases and terms were coded manually in order to highlight themes and patterns of meaning within data. This first phase led to code 523 utterances. These utterances, for example, include statements on the digital transformation of the economy, the economic opportunities provided by this technological shift to enterprises as well as the structural weaknesses that prevent enterprises to fully embrace this transformation.

We then looked for codes across interviews that could be grouped into higher-level themes. For example, comments on the digital transformation of the economy and the opportunities provided by this technological shift to enterprises, as well as the structural weaknesses that prevent enterprises to fully embrace this transformation could be grouped under the topics "Digital revolution" and "Structural weaknesses", forming a set of first-order categories.

We then established links among first-order categories in order to develop distinct clusters of themes in relation to different policy aspects. For example, categories containing instances of the growth opportunities provided by the digitalization of the economy and structural weaknesses that hamper this process collapsed into a theme called "The state of the Walloon digital sector".

Drawing on NPF concepts, the final step involved organizing thematic clusters into theoretical dimensions corresponding to NPF concepts. Themes 1 to 3 emphasize elements of the policy problem to be addressed and the context in which such problem takes place, and were therefore coded as Settings. Themes 4 to 11 highlight elements concerning the policy actors, and were therefore coded as Characters. Among them, Themes 4 and 5 were coded as Victims (those harmed by the problem), whereas Themes 6 and 7 identify the Heroes (those that provide or promise relief from the harm) and Themes 8 to 11 focus on the Villains (those who cause the harm). Themes 12 to 17 emphasize aspects of the policy solutions. As a result, they were coded as Moral of the story. Plots emerged from the interconnection of these elements and were defined by taking onto account the socio-economic indicators presented in Table 1.

Settings, characters, plots and morals of the story were validated through semi-structured interviews with the two regional officials in charge of smart city strategies in Brussels and Wallonia. Upon this validation, the findings were summarized in a table providing an overview of key narrative elements by region (rows) and NPF component (columns). Section 4, here below, provides extensive explanation of these findings.

\section{Findings}

\subsection{The settings}

"A policy narrative is directed towards addressing a specific policy problem and must situate that problem in a specific context" (Jones et al. 2014). The two strategies begin with exposing the problematic circumstances that form the setting for governmental action in the smart city domain. Both regional governments take for granted the fact that a digital revolution is on the way, i.e. a massive societal shift from mechanical and analogue electronic technology to digital electronics entailing an increasing adoption and proliferation of digital computers and digital record keeping in several domains of human life.

The digital revolution will radically redefine the competitiveness criteria of our territories, quality of services and well-being of people. From family to business, including public 
services, school, health or even culture, the digital shift is on the way. As Michel Serres states, this digital revolution will have effects as profound as the invention of writing and printing a long time ago. [Wallonia]

Digital networks are important to improve efficiency and, therefore, competitiveness. Today they fulfill the same essential role that the railways fulfilled in the $19^{\text {th }}$ century contributing to the industrial Revolution. Efficient connectivity is essential for everyone: the citizen, to learn, learn and access online services, the company for the same reasons and to develop its business online, to the public sector to offer innovative services. [Brussels]

However, the circumstances associated with this revolution vary across the narratives, with governments paying selective attention to certain aspects over others. In examining the myriad of contextual elements surrounding them, the Walloon and Brussels governments bring their focus on different socio-economic problems.

The Walloon government focuses on the unexploited growth potential of the digital revolution. It argues that, even though the digital sector is highly profitable, it still represents a small share of the regional economy. Within this context, smart urban territories are presented as a competitiveness factor which makes it possible to increase the number of firms operating in the digital sector. This narrative suggests that, equipped with a highly performing infrastructure in terms of connectivity, data storage and ICT applications, smart urban territories can become a place where digital enterprises - such as e-commerce firms and app developers - strive to establish themselves, thus creating new jobs and added value for the regional economy. The following quotes are exemplar:

The weight of the digital sector in the economy remains insufficient. It is underdeveloped. It captures only $10 \%$ of the total added value produced in the Belgian digital sector and represents a small share of the Walloon economy equal to $1.4 \%$ of GDP against $2.6 \%$ of GDP in Flanders.

Our territory must be seen as a real factor of competitiveness. Connected to very high speed and smart, it offers unlimited access to digital uses and acts as a catalyst for industrial and economic development.

$30 \mathrm{Mbps}$ connections are widely used in Wallonia. Acceptable for current uses, such connections will not be sufficient in the face of the profound evolution of online consumption patterns of businesses and citizens.

In contrast, the Brussels government brings attention on a new urban era characterized by multiple societal challenges. Within this context, the smart city concept is presented as the emerging policy framework to address such challenges. However, compared to other international metropolitan areas, Brussels lags behind in the smart city transition process, as also apparent in international benchmarks.

The city is the epicentre of the challenges of this $21^{\text {st }}$ century whether these challenges are about demography, prosperity, mobility, sustainability, or security.

City dwellers use $75 \%$ of the planet's natural resources while cities are responsible for $70 \%$ of greenhouse gas emissions. [...] Such environmental emergency pushes the city towards the path of sustainable development while the effects of past financial, social and economic crises still persist. Is the city's destiny too heavy for it to bear?

ICTs provide their solutions to the challenges of urban sustainable development: this is what an increasing number of cities, sometimes the most unexpected, have understood by defining their city project on the model of the smart city.

While several metropolises take first place in these rankings and are talked about in the international smart-city scene, the Brussels-Capital Region never appears there. 


\subsection{The cast of characters}

The different ways of interpreting the settings resulted in different configurations of the characters embedded in the policy narrative.

Within the Walloon narrative policy framework, regional economy and citizens emerge as the main victims of the unexploited growth potential of the digital sector. The economy suffers harm in the form of slow growth, which results into job losses and relatively low productivity, while citizens suffer from not having a vibrant and innovative digital sector. This sector is pictured as fundamental for providing public administrations with ICT solutions that can improve the quality of public service provision. The hero is equated with digital enterprises, in particular large tech companies. Companies operating in the ICT sector are presented as key actors which possess the financial resources needed to invest in ICT solutions for better-quality public services, thus creating new job opportunities and added value for the regional economy. Nevertheless, three threats (i.e. the villains) prevent digital enterprises from successfully completing their mission. Firstly, traditional administrative procedures burden entrepreneurship and inhibit the creation of new digital businesses. Secondly, urban territories characterized by insufficient coverage of telecoms network hampers cities' ability to store and speedily exchange data, while depriving digital enterprises of the physical infrastructure they need to operate their business. Thirdly, the low digital literacy of the majority of enterprises operating within the Walloon economy is deemed an obstacle to the overall regional market demand for ICT solutions provided by digital enterprises, representing a limit to their growth. Such a low literacy is accused of leaving the majority of Walloon enterprises deprived of the technological skills required to access and deploy the ICT solutions that digital enterprises can offer.

[The digital transformation] is a top priority in order to create value and jobs, and to ensure the well-being of all citizens.

ICT services enable us to envision a new generation of public services, open and transparent, both examples and vectors of a digital transformation that meets the needs of citizens as well as of other societal sectors.

Among the 3.509 enterprises composing the Walloon digital sector only 48 are large ones (less than $1 \%$ ) and 6 are very large. However, it is precisely these large enterprises that provide a strong contribution to employment $(24 \%)$ and to the creation of added value $(42 \%)$ in the digital sector. Moreover, with an annual growth rate of $12 \%$ since 2008 , these enterprises are the ones driving growth in the sector.

According to entrepreneurs, administrative formalities remain a major obstacle when it comes to the creation of a new company, hiring procedures, access to financial incentives, etc.

While $3 \mathrm{G}$ coverage in the country is close to $100 \%$, this is far from being the case for $4 \mathrm{G}$ [...]. This situation is detrimental to the development of new growth opportunities for our enterprises and to the development of new services for our citizens.

Walloon enterprises are lagging behind in the adoption and use of ICTs. This impacts their competitiveness and slows down the use of services offered by Walloon digital players, which also partly explains the small size of the digital sector.

In contrast, within the Brussels narrative policy framework, Brussels' dwellers - and, particularly young generations - emerge as the main victims of the upcoming societal challenges. The hero is equated with ICT solutions having the potential to solve not only environmental challenges, but also e-government, open government, and security challenges. 
E-government refers to new ICT opportunities for more direct connections between citizens and government. These digital solutions allow the latter to provide services directly to former while minimizing the intermediation of public bureaucracies. Linked to this is open government, which aims at applying the principle of freedom of information and holding that ICTs can improve citizens' right to access governmental documents, thus allowing for effective public oversight. Security refers to the use of cameras and video images to monitor city-life, as well as to prevent crimes and make urban rescue services more effective. However, such potential can be properly unleashed only if such solutions are framed within a global strategy that connects individual ICTs to regional policy needs. Therefore, the lack of a global vision on technological solutions in connection to policy is presented here as a threat that might complicate ICTs' mission of relieving young urban generations from contemporary societal challenges.

\footnotetext{
The smart city challenge is about bringing a higher quality of life to all the people, enterprises and organizations which "are" Brussels [...]. Failure is not allowed as not fully exploiting this potential equates to refusing to offer a future to our young generations.

We want to help the Brussels-Capital Region to improve the quality of life through ICT solutions that benefit $[\ldots]$ people, businesses and public administrations. To achieve this, we will address four challenges: [making Brussels] a connected, sustainable, open and secure region.

In a smart city, ICT sensors help governments to get their pulse on cities. More precisely, this is done thanks to video images. Cameras are indeed a crucial component of our urban systems of [crime] prevention, security and rescue services.

[...] ICTs are never an end in itself but an instrument to optimize our effectiveness. [...] It is therefore the lack of a global vision on the integration of ICTs in our regional policies [...] which prevents our Region from reaping their benefits.
}

\section{FIGURE 2 ABOUT HERE}

\subsection{Interpreting the plot: the moral of the story in the post-industrial city and in the global city}

Both governmental narratives framed smart city initiatives as instruments to be mobilized at the municipal level to take advantage of the ongoing digital revolution. Nevertheless, there are differences in the way governments interpret the settings, with each of them providing selective attention to different contextual elements with a corresponding plot and a causal arrangement of characters and policy solutions (the moral of the story). The dashboard of descriptive statistics in Figure 2 enables us to interpret these causal arrangements showing that regional governments operating in different socio-economic environments opt for distinct smart city models. More precisely, the holistic model is adopted in Brussels - a globalized and economically-prosperous region - whereas a narrower model is adopted in Wallonia - a former industrial, manufacturing area transitioning into the new economy with the ambition to become a hub for high-tech, digital businesses. While the latter proposes policy solutions bringing emphasis on business innovation ecosystems and digital skills training as a necessary accompaniment to create a trained workforce to support the digital transformation of the regional economy, the latter emphasizes ICT-driven solutions to improve the quality of public service provision, pollution control and civic accountability. 
Concerning economic prosperity, GDP per capita data indicate a clear gap between Wallonia and Brussels with the former featuring lower values than the latter. This difference is rooted in the recent history of the two regions and can be appreciated by looking at the fundamental characteristics of the two economies. In the mid- $20^{\text {th }}$ century, Wallonia underwent a profound economic crisis due to the decline of the heavy industry. On the contrary, Brussels - the capital of Belgium since the mid-19 $9^{\text {th }}$ century - flourished prosperously becoming a major centre for national and international politics, particularly for the EU, and one of the top financial centres of Western Europe. Nowadays, Brussels and Wallonia have thus two different economies with the former more service oriented than the latter. Indeed, $26 \%$ of Walloon enterprises operate in the manufacturing or construction sector (Brussels: 18\%); 34\% in general activities such as wholesale and retail trade, transportation and storage, accommodation and food services (Brussels: 29\%); 36\% provide services - i.e. real estate activities; professional, scientific, and technical activities; administration and support service activities - (Brussels: 45\%); and 4.6\% provide ICT services (Brussels: $8 \%$ ). ICT services indeed contribute more to the value produced by the Brussels enterprises than Walloon ones.

Nevertheless, with the adoption of the so-called Marshal Plan in 2004, Wallonia has started a profound process of economic restructuring aimed at increasing the weight of the ICT sector in the regional economy. This plan provides a strategy for the digital transformation of the regional economy and set the guidelines for the development of smart city initiatives. Within this framework, smart city development is understood as part of a wider effort of regional economic restructuring process where policymakers want to rejuvenate the urban productive structure of Wallonia by establishing it in the new economy. The Walloon smart city is thus a 'post-industrial city' in which the relative importance of manufacturing reduces but that of services, namely in the ICT sector, ambitions to grow.

The restructuring of the Walloon economy requires a strong and rapid increase in the digital intensity of all our businesses. This is essential for the emergence of an industry 4.0 and for ecommerce development.

[We want] to provide Wallonia with smart and connected territories where tech enterprises are recognized as world leaders and as the key drivers of a successful industrial transformation [...].

Key to this process are the digital enterprises and their business ecosystem, intended here as the environment composed of the sum total of non-digital enterprises, public administrations and other forces such as telecom networks that are outside the control of a digital enterprise but the digital enterprise still depends upon them as they affect the overall performance and sustainability of the digital business. As showed in the cast of characters presented above, the Walloon government estimates that a low digital literacy rate among non-digital enterprises along with burdening traditional public administration procedures and insufficient coverage of telecom networks are a threat to a positive business ecosystem. Thus, envisaged policy solutions bring the focus on ICT-related training programs and awareness campaigns aimed at strengthening the digital skills of the Walloon human capital, on the modernization of public administrations and on more investments in the digital infrastructure of Walloon territories.

Having fewer concerns in terms of ICT infrastructure coverage, human capital, ICT penetration at the enterprise level and administrative burden on entrepreneurs than Wallonia, the Brussels Region centres its smart city strategy around a broad-spectrum model characterized by a 
holistic approach to ICTs aimed at solving key human, economic and environmental issues of contemporary cities. The Brussels smart city is thus a 'global city' that follows the path of other major international metropolises adopting the smart city model to address a wide variety of future urban challenges.

[The Brussels Region] must bet on technologies as a lever for human, economic and environmental development.

In launching the 2011 preparatory works for the Regional Sustainable Development Plan adopted in September 2013, Minister-President Charles Picqué said: "In many respects, our Region follows the evolution of big metropolises, receptacles of the tensions of contemporary societies as well as of the forthcoming solutions because it is on these innovative territories that our future is being built."

Amsterdam, Berlin, Copenhagen and Vienna: 4 inspiring cities for our region. Why these four cities? First of all because they share many common points with our Region. These capitals are close by their size, their institutional status, their population or their economic and social context. In addition, all stand out in benchmarks, including Amsterdam, Copenhagen and Vienna, which are among the 6 most mature smart cities according to the Mapping Smart cities in the EU benchmark.

Key to this process are ICT solutions and the global vision behind their integration into existing urban systems in connection with those that in the eyes of governments are the most pressing urban challenges. As showed in the cast of characters, the Brussels government estimates that priority has to be given to (a) environmental sustainability, (b) e-government, (c) open government and (d) security. Thus, proposed solutions bring the focus on: (a) replacing paperwork with electronic procedures in public administrations to reduce the use of paper and car transfers from citizens' residences to municipal administrations in order to decrease the ecological footprint of public sector operations; (b) constructing new high-speed telecom networks and providing more urban areas with free Wi-Fi connection in order to facilitate online interactions between citizens and governments; (c) promoting open-data initiatives in order to improve citizens' conditions to access the documents and proceedings of the government; and (d) creating one single regional platform of video images collected by urban cameras in order to facilitate the day-to-day surveillance work of police services as well as of firemen, infrastructure managers, public transportation companies and urban waste managers.

Summing up, according to our analysis depending on the initial contextual premise of a region, a general narrative plot develops, which begins with generally consistent characters (victims, villains and heroes) and culminates in specific policy solutions (Table 2).

\section{TABLE 2 ABOUT HERE}

\section{Discussion}

Through an in-depth narrative analysis of the smart city strategies adopted by the Walloon and Brussels regional governments during the 2014-2019 period, this paper finds that regional governments operating within different socio-economic contexts develop different smart city policy narratives that reflect different place-based regional interpretations of the smart city concept. On the basis of these different interpretations, regional governments use smart city projects as policy instruments to overcome what they see as the most pressing socio-economic needs of their territories and populaces. Drawing on these findings, the paper provides three 
contributions. Firstly, it suggests that regional governments operating within different socioeconomic contexts can attribute different meanings to the smart city concept, thus opting for those smart city strategies that are best-situated in their contexts. Secondly, it unpacks two different regional strategies of smart city development showing that regional governments can use smart city initiatives as policy instruments to overcome a variety of place-based (environmental, social, and economic) sustainability problems. Thirdly, moving away from corporate-led deterministic models of smart city development, it invites to refuse the corporate one-size-fit-all approach to smart urbanism, thus calling for an active role of regional governments in the formulation of place-based smart city strategies that are consistent with the socio-economic needs and ambitions of their territories and populaces.

\subsection{Place-based regional interpretations of the smart city concept}

Policymakers' understanding of smart city development varies across municipalities of different size (Desdemoustier et al. 2019b). It therefore exists a relationship between policymakers' interpretation of smart cities and the socio-economic context in which they operate. Echoing Lu \& de Jong (2019), we particularly argue that policy-makers' choices about smart city models are not made in a void but based on their interpretation of existing socioeconomic and regional contexts. Consistently with Tang et al. (2019), we show that policymakers operating in major economically-prosperous regional areas embedding national capitals choose the holistic smart city model; whereas the narrower technology-focused model prevails in areas transitioning from former logistic hubs and manufacturing centers into the new economy to become hubs for high-tech business. Through a narrative analysis of regional smart city strategy texts in Wallonia and Brussels, our study offers evidence about the different regional socio-economic profiles which can be associated with different smart city choices. According to our findings, in the Brussels region, the economy is more service-oriented, the perceived administrative burden on entrepreneurs is relatively low, and there are relatively high levels of GDP per capita, human capital, ICT infrastructural coverage, and ICT penetration in enterprises. In this context, a holistic model of smart city development prevails. Conversely, the Walloon region has a less service-oriented economy, the perceived administrative burden on entrepreneurs is relatively high and there are relatively low levels of GDP per capita, human capital, ICT infrastructural coverage and ICT penetration in enterprises. In this regional area, a more narrowly technology-focused approach to smart city development has been selected.

Joss et al. (2019) argue that smart city development models are increasingly adopted worldwide, and their diffusion is centered upon different narrative frameworks. Their work sheds light on narratives developed in global city contexts, including the Brussels area. Consistently with our findings, their analysis suggests that policymakers operating in such contexts posit their territories at the vanguard of the smart city innovation adopting holistic narratives that they use "concurrently to promote urban renewal to their domestic audiences and to signal their global ambitions to foreign audiences, and in doing so frequently engaging in mutual cross-referencing and benchmarks" (Joss et al. 2019: 23). In addition to this, our findings provide insights into the smart city policy narrative developed in a post-industrial context such as the Wallonia region. Urban studies research on such contexts explains that the attention of policymakers usually revolves around a narrative of advanced, technology-driven 
production, giving priority to business services and tech-driven development with a key role played by Industry 4.0 agenda, including production through robotics, automation, and data analytics (Grodach \& Martin, 2020; Schwab, 2016). Consistently with this research perspective, our study indicates that policymakers understand the smart city transformational process as an opportunity to develop competitive economic advantages through technological leadership. Their ambition is to transit the urban economy from former manufacturing centers into the post-industrial, knowledge economy era.

\subsection{Regional strategies of smart city development}

Echoing Desdemoustier et al. (2019a) and Lu \& de Jong (2019), our findings show that, despite different narrative policy frameworks across jurisdictions, smart city initiatives can be understood as policy instruments (Lascoumes and Le Gales 2007) designed and implemented by governments to achieve a variety of environmental, social, and economic sustainability goals. In the Wallonia region, the narrative plot frames smart cities as an instrument to transform the former industrial, manufacturing urban areas of the region into hubs for hightech, digital businesses. In the Brussels region, the narrative plot frames smart cities as an instrument to tackle a number of societal challenges - such as sustainable development, democratic governance and urban security - that are already a priority on the agenda of other important international metropolises. Our analysis particularly suggests adopting a multilevel perspective with supra-municipal authorities (i.e. regional governments) framing smart city projects to be developed at the municipal level as instruments to achieve supra-municipal policy objectives linked to ongoing processes of strategic change.

Operating within a post-industrial environment, the Walloon government frames the smart city development of its municipalities in relation to the digital transformation of the regional economy. Therefore, Giffinger et al.'s (2007) 'smart economy' and 'smart people' measures feature high in the policy text of this region, including for example economic incentives to support the growth of digital enterprises and ICT training program to strengthen the human capital. Conversely, operating within a global city environment, the Brussels government frames the smart city development of its municipalities in relation to the overpopulation and environmental problems that are progressively undermining the quality of life of urban dwellers. Giffinger et al.'s (2007) 'smart governance', 'smart environment' and 'smart living' measures feature high in the policy text of this region, including e-democracy solutions to enhance citizens' interactions with the public sector, ICT solutions to replace administrative paperwork with electronic procedures to reduce the footprint of public administrations, and surveillance cameras to render the street life more secure.

These two strategies have a promising heuristic potential for future analyses and, on a more practical level, for policy design. Indeed, similar strategies can be found in urban environments that exhibit socio-economic profiles that are similar to those examined in this paper (Tang et al. 2019). For example, old industrial and trading urban areas such as Edinburgh, Lyon and Toronto have also embraced smart city models that are instrumental to their economic transformation into hubs for high-tech innovative business. Conversely, globalized and economically-prosperous urban areas in Europe and North America (e.g. Barcelona, Berlin, London and Vancouver) also emphasize smart city strategies aimed at improving the quality 
of life through more efficient and effective urban services (e.g. local security, water, or waste management), introducing technological solutions for pollution control (e.g. clean energy, smart lighting, environmental protection) and, to a lesser extent, facilitating civic participation in the city governance.

\subsection{One-size-does-not-fit-all: for an active role of regional governments in the formulation of place-based smart city strategies}

In pointing to the role of policy narratives and policymakers' understanding and definition of smart city plans, our findings emphasize the importance of agency in smart city development. It particularly conceives agency in the form of policy narratives crafted by regional governments to make sense of the spreading smart city paradigm as well as of the urban problems that can be fixed through the design and implementation ICT solutions. Echoing Tang et al. (2019), we argue that regional governments choose to adopt different smart city plans because they operate in different urban (socio-economic) environments whose residents experience different practical problems and direct policy makers to design and implement different ICT solutions to solve them. Such environments might act as cognitive filters that shape policymakers' perceptions about what is feasible, legitimate, possible and desirable (Hay \& Wincott, 1998), thus influencing key strategic decisions about the smart city model that is more appropriate to existing socio-economic circumstances. These findings invite to think more about the varieties of smart city arrangements that might develop in different institutional environments. Building on a public governance approach to smart cities (Meijer, 2018) and political economy theories of business-politics relations (Culpepper, 2010), Drapalova \& Wegrich (2020) identify varieties of smart cities along two major dimensions, namely the magnitude of citizen mobilization and the degree of politicization and direct involvement of elected politicians. Through different combinations of these dimensions they identify four varieties of smart city governance: citizen-centred, disjointed, weak business-politics coalition and captured city. This framework relates citizens' mobilization and political leadership as primary factors that can influence the smart city model and the role that companies and other actors play in it. In pointing to the role of citizens' mobilization and political leadership, Drapalova \& Wegrich (2020) emphasize the importance of agency in smart city varieties. Drawing on Hall \& Soskice (2001), we argue that smart city varieties can be also linked to differences in economic, technological and human environments within which smart-city actors operate. Particularly, our findings suggest that well-established knowledge-economy environments characterized by technological as well as human capital abundancy are fertile institutional environments for the adoption of holistic, broad spectrum smart city plans whereas environments consisting of less mature (economic, technological, human) institutions may be fertile grounds for more narrowly-focused approaches to smart city development, such as the business ecosystem approach.

These findings have important practical implications. They invite governments to refuse the deterministic, one-size-fits-all mentality of smart city development - which dominates the corporate understanding of smart urbanism (Luque-Ayala \& Marvin, 2015) - in order to embrace a place-based approach. Technological determinism prompts a reductionist view of urban technological innovation, which is understood as a mere technical process, taking place 
outside social, political, organizational, and cultural settings (Pritchard \& Brittain, 2015). Conversely, this study shows that urban technological deployment is socially-constructed process whereby governments attribute different meanings to technology and select among multiple alternative choices the smart city model that is more aligned with the economic, technological and human characteristics of their territories. In other words, our narrative analysis demonstrates that there is much more than the corporate-led one-size-fit-all mentality. Governments can choose to formulate their smart city policies in alignment to their socioeconomic contexts, seeking to advance technological solutions to what they perceive as the most pressing issues on their political agendas and a "desired urban development" (Verrest \& Pfeffer, 2019: 1329). Consistently with the cognitive approach to policy-making (Jones et al., 2014; Weible \& Sabatier, 2017), our findings point to the power of interpreting and defining urban issues as central to smart city policy outcomes. We particularly suggest that the way governments understand and label urban challenges is key to determine smart city policy interventions, thus inviting future research to pay more attention to actors' discourses about smart city development and the socio-economic environments in which these discourses are embedded.

\section{Conclusion}

Innovatively building on NPF, we argue that regional governments operating within different socio-economic contexts develop different smart city policy narratives because they have different place-based regional interpretations of the smart city concept. Because of these different interpretations, such governments understand and use smart city projects as policy instruments to solve what they consider the most pressing socio-economic problems of their territories and populaces. These findings allow for three key policy recommendations. Firstly, we recommend policy-makers to adopt a place-based approach to smart city development in order to design and implement smart city strategies that are well-situated in their socioeconomic contexts. Secondly, we recommend policy-makers to see smart technologies as means - and not as ends in themselves - thus suggesting to use smart city projects as policy instruments to address the most pressing socio-economic problems of their territories and populaces. Thirdly we recommend government to adopt an active role in the formulation of smart city policies by designing and implementing strategies that are aligned with the socioeconomic needs and ambitions of their territories and populaces.

Based on an in-depth analysis of the Walloon and Brussels cases, this paper has identified two strategies of smart city development that are well-suited in two particular socio-economic contexts. On the one hand, with an emphasis on ICT solutions in government and administration to improve civic participation, urban services and pollution control, the holistic strategy might be well-suited in urban environments that - such as the Brussels region - are economically prosperous and/or embed provincial or national capitals. Conversely, with an emphasis on business innovation and digital skills training programs to create a trained urban workforce, a narrower approach might be well suited in urban environments - such as the Wallonia region - that are transitioning from former logistic hubs and manufacturing centers into the new economy to become hubs for high-tech business. These findings suggest further exploring the hypothesis that well-established knowledge-economy environments 
characterized by technological as well as human capital abundancy are fertile institutional environments for the adoption of holistic, broad spectrum smart city strategies whereas environments consisting of less mature (economic, technological, human) institutions may be fertile grounds for more narrowly-focused approaches. Even though these two regional strategies have promising heuristic potential for future analyses, it is worth remembering that they emerge from an exploratory comparative case-study analysis involving only two regions. Therefore, further empirical analysis is certainly needed in the future to generalize this emerging hypothesis. In this regard, we suggest to test the above-mentioned hypothesis on a large sample of regions, looking for more robust correlations between the typology of smart city strategy adopted by regional governments and the socio-economic parameters of the local contexts within which governments are situated (e.g. economy, human capital and digital infrastructure). In this case, data availability is certainly a major problem that can be possibly overcome through surveys addressing residents in (supra-)municipal administrations.

\section{References}

Acuto, M., \& Parnell, S. (2016). Leave no city behind. Science, 352(6288), 873-873. https://doi.org/10.1126/science.aag1385

Adapa, A., Nah, F. F.-H., Hall, R. H., Siau, K., \& Smith, S. N. (2018). Factors Influencing the Adoption of Smart Wearable Devices. International Journal of Human-Computer Interaction, 34(5), 399-409. https://doi.org/10.1080/10447318.2017.1357902

Angelidou, M. (2014). Smart city policies: A spatial approach. Cities, 41, S3-S11. https://doi.org/10.1016/j.cities.2014.06.007

Angelidou, M., Psaltoglou, A., Komninos, N., Kakderi, C., Tsarchopoulos, P., \& Panori, A. (2018). Enhancing sustainable urban development through smart city applications. Journal of Science and Technology Policy Management, 9(2), 146-169. https://doi.org/10.1108/JSTPM-05-2017-0016

Anthopoulos, L. (2017). Smart utopia VS smart reality: Learning by experience from 10 smart city cases. Cities, 63, 128-148. https://doi.org/10.1016/j.cities.2016.10.005

Appio, F. P., Lima, M., \& Paroutis, S. (2019). Understanding Smart Cities: Innovation ecosystems, technological advancements, and societal challenges. Technological Forecasting and Social Change, 142, 1-14.

https://doi.org/10.1016/j.techfore.2018.12.018 
Ashworth, G. J., \& Voogd, H. (1990). Selling the city: Marketing approaches in public sector urban planning. Belhaven Press.

Barry, D., \& Elmes, M. (1997). Strategy Retold: Toward a Narrative View of Strategic Discourse. Academy of Management Review, 22(2), 429-452. https://doi.org/10.5465/amr.1997.9707154065

Batty, M., Axhausen, K. W., Giannotti, F., Pozdnoukhov, A., Bazzani, A., Wachowicz, M., Ouzounis, G., \& Portugali, Y. (2012). Smart cities of the future. The European Physical Journal Special Topics, 214(1), 481-518. https://doi.org/10.1140/epjst/e2012-01703-3

Cowley, R., Joss, S., \& Dayot, Y. (2018). The smart city and its publics: Insights from across six UK cities. Urban Research \& Practice, 11(1), 53-77. https://doi.org/10.1080/17535069.2017.1293150

Crivello, S. (2015). Urban Policy Mobilities: The Case of Turin as a Smart City. European Planning Studies, 23(5), 909-921. https://doi.org/10.1080/09654313.2014.891568

Csukás, M. S., \& Szabó, R. Z. (2021). The many faces of the smart city: Differing value propositions in the activity portfolios of nine cities. Cities, 112, 103116. https://doi.org/10.1016/j.cities.2021.103116

Culpepper, P. D. (2010). Quiet Politics and Business Power: Corporate Control in Europe and Japan. Cambridge University Press.

de Jong, M., Chen, Y., Joss, S., Lu, H., Zhao, M., Yang, Q., \& Zhang, C. (2018). Explaining city branding practices in China's three mega-city regions: The role of ecological modernization. Journal of Cleaner Production, 179, 527-543. https://doi.org/10.1016/j.jclepro.2018.01.098 
de Jong, M., Yu, C., Joss, S., Wennersten, R., Yu, L., Zhang, X., \& Ma, X. (2016). Eco city development in China: Addressing the policy implementation challenge. Journal of Cleaner Production, 134, 31-41. https://doi.org/10.1016/j.jclepro.2016.03.083

Desdemoustier, J., Crutzen, N., Cools, M., \& Teller, J. (2019). Smart City appropriation by local actors: An instrument in the making. Cities, 92, 175-186.

https://doi.org/10.1016/j.cities.2019.03.021

Desdemoustier, J., Crutzen, N., \& Giffinger, R. (2019). Municipalities' understanding of the Smart City concept: An exploratory analysis in Belgium. Technological Forecasting and Social Change, 142, 129-141. https://doi.org/10.1016/j.techfore.2018.10.029

Destatte, P. (1997). L'identité wallonne: Essai sur l'affirmation politique de la Wallonie aux XIX et XXèmes siècles. Institut Jules Destrée.

Drapalova, E., \& Wegrich, K. (2020). Who governs 4.0? Varieties of smart cities. Public Management Review, 22(5), 668-686. https://doi.org/10.1080/14719037.2020.1718191

Esposito, G., Nelson, T., Ferlie, E., \& Crutzen, N. (2021). The institutional shaping of global megaprojects: The case of the Lyon-Turin high-speed railway. International Journal of Project Management. https://doi.org/10.1016/j.ijproman.2021.06.001

Esposito, G., Terlizzi, A., \& Crutzen, N. (2020). Policy narratives and megaprojects: The case of the Lyon-Turin high-speed railway. Public Management Review, 1-25. https://doi.org/10.1080/14719037.2020.1795230

European Commission. (2018). Digital Economy and Society Index (DESI), 2018 Country Report Belgium (Country Reports). European Union. https://ec.europa.eu/information_society/newsroom/image/document/2018-20/bedesi_2018-country-profile_eng_199603A9-AB53-4E2103C0BEF3730537BA_52213.pdf 
Eurostat. (2019). GDP per capita in 281EU regions (No. 34; Eurostat Newsrelease). https://ec.europa.eu/eurostat/documents/2995521/9618249/1-26022019-APEN.pdf/f765d183-c3d2-4e2f-9256-cc6665909c80

Flyvbjerg, B. (2001). Making social science matter: Why social inquiry fails and how it can succeed again. Cambridge University Press.

Gerring, J. (2006). Case Study Research: Principles and Practices. Cambridge University Press.

Gibbs, G. R. (2007). Analyzing Qualitative Data. SAGE. https://methods.sagepub.com/book/analyzing-qualitative-data/n4.xml

Giffinger, R., Fertner, C., Kramar, H., \& Meijers, E. (2007). City-ranking of European Medium-Sized Cities. 12.

Gioia, D. A., Corley, K. G., \& Hamilton, A. L. (2013). Seeking Qualitative Rigor in Inductive Research: Notes on the Gioia Methodology. Organizational Research Methods, 16(1), 15-31. https://doi.org/10.1177/1094428112452151

Gray, G., \& Jones, M. D. (2016). A qualitative narrative policy framework? Examining the policy narratives of US campaign finance regulatory reform: Public Policy and Administration. https://doi.org/10.1177/0952076715623356

Greco, I., \& Bencardino, M. (2014). The Paradigm of the Modern City: SMART and SENSEable Cities for Smart, Inclusive and Sustainable Growth. In B. Murgante, S. Misra, A. M. A. C. Rocha, C. Torre, J. G. Rocha, M. I. Falcão, D. Taniar, B. O. Apduhan, \& O. Gervasi (Eds.), Computational Science and Its Applications - ICCSA 2014 (pp. 579-597). Springer International Publishing. https://doi.org/10.1007/978-3319-09129-7_42

Greimas, A. J. (1983). Structural semantics: An attempt at a method. University of Nebraska Press. http://books.google.com/books?id=VvRYAAAAMAAJ 
Grodach, C., \& Martin, D. (2020). Zoning in on urban manufacturing: Industry location and change among low-tech, high-touch industries in Melbourne, Australia. Urban Geography. https://doi.org//10.1080/02723638.2020.1723329

Hall, P. A., \& Soskice, D. (2001). Varieties of Capitalism. Oxford University Press. https://doi.org/10.1093/0199247757.001.0001

Han, M., De Jong, M., Cui, Z., Xu, L., Lu, H., \& Sun, B. (2018). City Branding in China's Northeastern Region: How Do Cities Reposition Themselves When Facing Industrial Decline and Ecological Modernization? Sustainability, 10(1), 102. https://doi.org/10.3390/su10010102

Hay, C., \& Wincott, D. (1998). Structure, Agency and Historical Institutionalism. Political Studies, 46(5), 951-957. https://doi.org/10.1111/1467-9248.00177

Hollands, R. G. (2008). Will the real smart city please stand up? City, 12(3), 303-320. https://doi.org/10.1080/13604810802479126

Ibrahim, M., El-Zaart, A., \& Adams, C. (2018). Smart sustainable cities roadmap: Readiness for transformation towards urban sustainability. Sustainable Cities and Society, 37, 530-540. https://doi.org/10.1016/j.scs.2017.10.008

Johnson, R. B., \& Onwuegbuzie, A. J. (2016). Mixed Methods Research: A Research Paradigm Whose Time Has Come: Educational Researcher. https://doi.org/10.3102/0013189X033007014

Jones, M. D. (2014). Cultural Characters and Climate Change: How Heroes Shape Our Perception of Climate Science. Social Science Quarterly, 95(1), 1-39. https://doi.org/10.1111/ssqu.12043

Jones, M. D., McBeth, M. K., \& Shanahan, E. A. (2014). Introducing the Narrative Policy Framework. In M. D. Jones, E. A. Shanahan, \& M. K. McBeth (Eds.), The Science of 
Stories: Applications of the Narrative Policy Framework in Public Policy Analysis (pp. 1-25). Palgrave Macmillan US. https://doi.org/10.1057/9781137485861_1 Joss, S., Sengers, F., Schraven, D., Caprotti, F., \& Dayot, Y. (2019). The Smart City as Global Discourse: Storylines and Critical Junctures across 27 Cities. Journal of Urban Technology, 26(1), 3-34. https://doi.org/10.1080/10630732.2018.1558387

Karppi, I., \& Vakkuri, J. (2020). Becoming smart? Pursuit of sustainability in urban policy design. Public Management Review, 22(5), 746-766. https://doi.org/10.1080/14719037.2020.1718188

Kitchin, R. (2015). Making sense of smart cities: Addressing present shortcomings. Cambridge Journal of Regions, Economy and Society, 8(1), 131-136. https://doi.org/10.1093/cjres/rsu027

Korachi, Z., \& Bounabat, B. (2020). Towards a Frame of Reference for Smart City Strategy Development and Governance. Journal of Computer Science, 15.

Lascoumes, P., \& Le Gales, P. (2007). Introduction: Understanding Public Policy through Its Instruments-From the Nature of Instruments to the Sociology of Public Policy Instrumentation. Governance, 20(1), 1-21. https://doi.org/10.1111/j.14680491.2007.00342.x

Lazaroiu, G. C., \& Roscia, M. (2012). Definition methodology for the smart cities model. Energy, 47(1), 326-332. https://doi.org/10.1016/j.energy.2012.09.028

Li, J., \& Wang, X. (2012). Energy and climate policy in China's twelfth five-year plan: A paradigm shift. Energy Policy, 41, 519-528. https://doi.org/10.1016/j.enpol.2011.11.012

Liu, H., Zhou, G., Wennersten, R., \& Frostell, B. (2014). Analysis of sustainable urban development approaches in China. Habitat International, 41, 24-32. https://doi.org/10.1016/j.habitatint.2013.06.005 
Lorquet, A., \& Pauwels, L. (2020). Interrogating urban projections in audio-visual 'smart city' narratives. Cities, 100, 102660. https://doi.org/10.1016/j.cities.2020.102660

Lu, H., \& de Jong, M. (2019). Evolution in city branding practices in China's Pearl River Delta since the year 2000. Cities, 89, 154-166. https://doi.org/10.1016/j.cities.2019.01.026

Luque-Ayala, A., \& Marvin, S. (2015). Developing a critical understanding of smart urbanism?: Urban Studies. https://doi.org/10.1177/0042098015577319

Meijer, A. (2018). Datapolis: A Public Governance Perspective on "Smart Cities". Perspectives on Public Management and Governance, 1(3), 195-206. https://doi.org/10.1093/ppmgov/gvx017

Meijer, A., \& Bolívar, M. P. R. (2016). Governing the smart city: A review of the literature on smart urban governance. International Review of Administrative Sciences, 82(2), 392-408. https://doi.org/10.1177/0020852314564308

Merrilees, B., Miller, D., \& Herington, C. (2012). Multiple stakeholders and multiple city brand meanings. European Journal of Marketing, 46(7/8), 1032-1047. https://doi.org/10.1108/03090561211230188

Mora, L., \& Deakin, M. (2019). Untangling Smart Cities: From Utopian Dreams to Innovation Systems for a Technology-Enabled Urban Sustainability. Elsevier.

Mora, L., Deakin, M., \& Reid, A. (2019a). Combining co-citation clustering and text-based analysis to reveal the main development paths of smart cities. Technological Forecasting and Social Change, 142, 56-69. https://doi.org/10.1016/j.techfore.2018.07.019

Mora, L., Deakin, M., \& Reid, A. (2019b). Strategic principles for smart city development: A multiple case study analysis of European best practices. Technological Forecasting and Social Change, 142, 70-97. https://doi.org/10.1016/j.techfore.2018.07.035 
Nam, T., \& Pardo, T. A. (2011). Smart city as urban innovation: Focusing on management, policy, and context. Proceedings of the 5th International Conference on Theory and Practice of Electronic Governance, 185-194. https://doi.org/10.1145/2072069.2072100

Nesti, G., \& Graziano, P. R. (2020). The democratic anchorage of governance networks in smart cities: An empirical assessment. Public Management Review, 22(5), 648-667. https://doi.org/10.1080/14719037.2019.1588355

Potter, E. (2020). Contesting imaginaries in the Australian city: Urban planning, public storytelling and the implications for climate change. Urban Studies, 57(7), 15361552.

Pritchard, G. W., \& Brittain, K. (2015). Alarm pendants and the technological shaping of older people's care: Between (intentional) help and (irrational) nuisance. Technological Forecasting and Social Change, 93, 124-132. https://doi.org/10.1016/j.techfore.2014.07.009

Ramaswami, A., Russell, A. G., Culligan, P. J., Sharma, K. R., \& Kumar, E. (2016). Metaprinciples for developing smart, sustainable, and healthy cities. Science, 352(6288), 940-943. https://doi.org/10.1126/science.aaf7160

Ruhlandt, R. W. S. (2018). The governance of smart cities: A systematic literature review. Cities, 81, 1-23. https://doi.org/10.1016/j.cities.2018.02.014

Sadowski, J., \& Bendor, R. (2019). Selling Smartness: Corporate Narratives and the Smart City as a Sociotechnical Imaginary. Science, Technology, \& Human Values, 44(3), 540-563. https://doi.org/10.1177/0162243918806061

Sancino, A., \& Hudson, L. (2020). Leadership in, of, and for smart cities - case studies from Europe, America, and Australia. Public Management Review, 22(5), 701-725. https://doi.org/10.1080/14719037.2020.1718189 
Sandercock, L. (2003). Out of the Closet: The Importance of Stories and Storytelling in Planning Practice. Planning Theory \& Practice, 4(1), 11-28. https://doi.org/10.1080/1464935032000057209

Schwab, K. (2016). The Fourth Industrial Revolution. World Economic Forum.

Shapiro, J. M. (2006). Smart Cities: Quality of Life, Productivity, and the Growth Effects of Human Capital. The Review of Economics and Statistics, 88(2), 324-335.

Shelton, T., Zook, M., \& Wiig, A. (2015). The 'actually existing smart city'. Cambridge Journal of Regions, Economy and Society, 8(1), 13-25. https://doi.org/10.1093/cjres/rsu026

Simonofski, A., Asensio, E. S., De Smedt, J., \& Snoeck, M. (2019). Hearing the Voice of Citizens in Smart City Design: The CitiVoice Framework. Business \& Information Systems Engineering, 61(6), 665-678. https://doi.org/10.1007/s12599-018-0547-z

Söderström, O., Paasche, T., \& Klauser, F. (2014). Smart cities as corporate storytelling. City, 18(3), 307-320. https://doi.org/10.1080/13604813.2014.906716

Tang, Z., Jayakar, K., Feng, X., Zhang, H., \& Peng, R. X. (2019). Identifying smart city archetypes from the bottom up: A content analysis of municipal plans. Telecommunications Policy, 43(10), 101834. https://doi.org/10.1016/j.telpol.2019.101834

Throgmorton, J. A. (2003). Planning as Persuasive Storytelling in a Global-Scale Web of Relationships. Planning Theory, 2(2), 125-151. https://doi.org/10.1177/14730952030022003

Timeus, K., Vinaixa, J., \& Pardo-Bosch, F. (2020). Creating business models for smart cities: A practical framework. Public Management Review, 22(5), 726-745. https://doi.org/10.1080/14719037.2020.1718187 
Torfing, J. (2016). Collaborative Innovation in the Public Sector. Georgetown University Press; JSTOR. https://www.jstor.org/stable/j.ctt1h64pfm

United Nations (Ed.). (2015). Transforming Our World: The 2030 Agenda for Sustainable Development. United Nations; A/RES/70/1. https://www.un.org/ga/search/view_doc.asp?symbol=A/RES/70/1\&Lang=E

Van den Bergh, J., \& Viaene, S. (2016). Unveiling smart city implementation challenges: The case of Ghent. Information Polity, 21(1), 5-19. https://doi.org/10.3233/IP-150370

Verrest, H., \& Pfeffer, K. (2019). Elaborating the urbanism in smart urbanism: Distilling relevant dimensions for a comprehensive analysis of Smart City approaches. Information, Communication \& Society, 22(9), 1328-1342. https://doi.org/10.1080/1369118X.2018.1424921

Viitanen, J., \& Kingston, R. (2014). Smart Cities and Green Growth: Outsourcing Democratic and Environmental Resilience to the Global Technology Sector: Environment and Planning A. https://doi.org/10.1068/a46242

Visser, R. (2019). Posthuman policies for creative, smart, eco-cities? Case studies from China. Environment and Planning A: Economy and Space, 51(1), 206-225. https://doi.org/10.1177/0308518X18765481

Wahlström, M. H., Kourtit, K., \& Nijkamp, P. (2020). Planning Cities4People-A body and soul analysis of urban neighbourhoods. Public Management Review, 22(5), 687-700. https://doi.org/10.1080/14719037.2020.1718190

Walravens, N. (2015). Qualitative indicators for smart city business models: The case of mobile services and applications. Telecommunications Policy, 39(3), 218-240. https://doi.org/10.1016/j.telpol.2014.12.011

Washburn, D., \& Sindhu, U. (2010). Helping CIOs Understand "Smart City” Initiatives. Smart City, 17. 
Weible, C. M., \& Sabatier, P. A. (2017). Theories of the Policy Process. European Policy Analysis, 3(2), 397-397. https://doi.org/10.1002/epa2.1023

Weick, K. E. (1995). Sensemaking in Organizations. SAGE.

Weick, K. E., Sutcliffe, K. M., \& Obstfeld, D. (2005). Organizing and the Process of Sensemaking. Organization Science, 16(4), 409-421.

https://doi.org/10.1287/orsc.1050.0133

Yang, C., \& Li, S. (2013). Transformation of cross-boundary governance in the Greater Pearl River Delta, China: Contested geopolitics and emerging conflicts. Habitat International, 40, 25-34. https://doi.org/10.1016/j.habitatint.2013.02.001

Ye, L. (2014). State-led metropolitan governance in China: Making integrated city regions.

Cities, 41, 200-208. https://doi.org/10.1016/j.cities.2014.03.001

Yin, R. K. (2014). Case Study Research. SAGE Publications. 